\title{
KAJIAN CONDITIONAL BETA DI BURSA EFEK INDONESIA
}

\author{
Yuvica Lara Rovantiane \\ Universitas Kristen Satya Wacana, Indonesia \\ Robiyanto* \\ Universitas Kristen Satya Wacana, Indonesia \\ *robiyanto.robiyanto@uksw.edu
}

\begin{abstract}
Abstrak
Penelitian ini mengkaji risiko sistematis pada dua periode pasar yang berbeda (bearish dan bullish) di Bursa Efek Indonesia (BEI), serta meneliti apakah terdapat perbedaan risiko sistematis pada kedua periode pasar tersebut. Data yang digunakan dalam penelitian ini adalah data harga saham penutupan harian saham terpilih dan penutupan harian Indeks Harga Saham Gabungan (IHSG) periode 2 Januari 2017 sampai dengan 30 Desember 2020, dengan data yang diperoleh dari Investing.com. Metode pengambilan sampel yang digunakan adalah metode purposive sampling dengan kriteria tidak pernah melakukan stock split, tidak pernah dihentikan sementara (suspensed), dan diperdagangkan secara aktif selama periode pengamatan, agar tidak terjadi bias. Sebanyak 20 saham ditemukan yang memenuhi kriteria tersebut. Hasil penelitian menunjukkan bahwa tidak ada perbedaan antara bull dan bear beta. Kemudian, tidak ada perbedaan antara periode keseluruhan dan bull atau bear beta. Temuan menyiratkan bahwa investor dan manajer portofolio dapat menggunakan semua periode beta sebagai proksi risiko sistematis mereka.
\end{abstract}

Kata Kunci: Periode Bullish, Periode Bearish, Beta, Risiko Sistematis, IHSG

\section{Pendahuluan}

Investasi di pasar modal merupakan aktivitas penanaman modal baik jangka pendek maupun jangka panjang dengan harapan akan memperoleh keuntungan di masa yang akan datang (Mudjiyono, 2018). Investasi di pasar modal tidak terlepas dari adanya risiko dan tingkat pengembalian (return) yang diharapkan oleh investor. Hubungan risiko dengan return adalah hubungan yang searah (Khoiriah et al, 2020). Artinya, apabila semakin besar tingkat risiko, maka tingkat return yang diharapkan akan semakin besar, begitupun sebaliknya. Investor sering kali melakukan diversifikasi saham dengan mengkombinasikan beberapa saham di portofolionya, tujuannya agar mendapatkan return yang optimal dengan tingkat risiko yang minimal (Febriyanti, 2020).

Secara umum, risiko dalam berinvestasi dibagi menjadi dua, yaitu risiko sistematis dan risiko tidak sistematis. Risiko sistematis atau risiko pasar menurut Robiyanto \& Pangestuti (2020) adalah risiko yang berasal dari kondisi ekonomi dan kondisi pasar secara luas yang tidak bisa didiversifikasikan yang diukur dengan menggunakan beta $(\beta)$. Sedangkan, risiko tidak sistematis adalah risiko yang dapat dihindari melalui diversifikasi. Nilai beta $(\beta)$ merupakan simbol untuk menilai kerentanan saham (volatilitas saham) terhadap pasar (Tandelilin, 2001). Artinya, nilai beta digunakan oleh investor sebagai indikator dalam menghitung risiko yang berkaitan dengan tingkat return suatu saham.

Risiko sistematis terjadi pada tahun 2020, krisis keuangan global terjadi akibat adanya pandemi COVID-19. Sejak bulan Maret 2020, Organisasi Kesehatan Dunia (WHO) 
mengumumkan bahwa COVID-19 adalah wabah pandemi global (Susanti et al, 2020).Virus yang menyerang sistem pernapasan ini menyebar begitu cepat. Penyebaran yang cepat ini memberikan dampak yang signifikan terhadap perekonomian negara-negara yang terjangkit dan mengakibatkan pemerintah melakukan pembatasan terhadap aktivitas ekonomi dunia, termasuk Indonesia. Dari kondisi ekonomi global tersebut, membuat mental investor menjadi panik, khawatir dan menyebabkan pasar saham global mengalami tekanan yang hebat sehingga membuat investor melepaskan kepemilikan sahamnya (Sumiari \& Putri, 2020). Namun, Indeks Harga Saham Gabungan (IHSG) perlahan mulai mengalami pemulihan (recovery) dan investor mulai optimis untuk melakukan investasi saham.

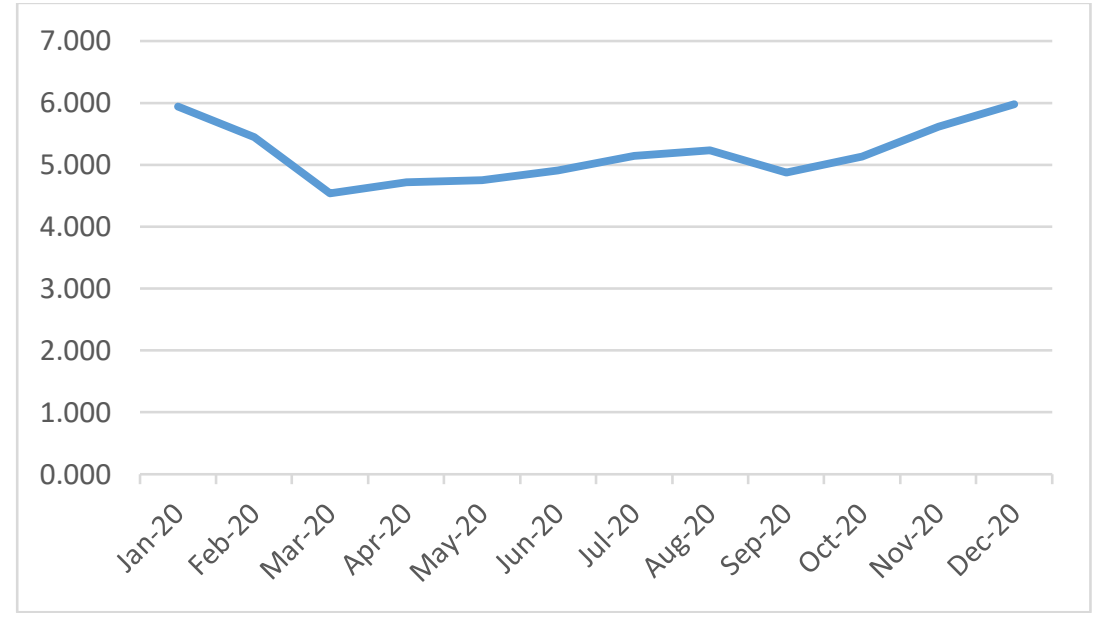

Gambar 1. Grafik Pergerakan IHSG Tahun 2020

(Sumber: Investing.com, data diolah)

Beberapa penelitian telah dilakukan mengenai beta saham pada kondisi pasar sedang bullish dan bearish. Penelitian Hadita (2011), Yunita (2018), Partono Thomas, Widiyanto, (2019) menemukan adanya hubungan positif signifikan antara perbandingan kinerja portofolio saham dengan menggunakan Single Index Model. Ariasih \& Mustanda, (2018), Ikadarma, Yandi; Bertuah, (2019) menemukan adanya hubungan negatif signifikan antara conditional beta dengan return saham menggunakan metode Single Index Model. Penelitian Sembiring et al, (2017), Respati et al, (2018), Susanti et al, (2020) menemukan adanya hubungan positif signifikan antara conditional beta dengan return saham menggunakan metode CAPM serta penelitian Sudarsono et al, (2017), Teh \& Lau (2017) menemukan adanya pengaruh negatif dengan menggunakan metode conditional CAPM.

Penelitian ini dilakukan karena adanya kejadian luar biasa yakni pandemi COVID-19. Berbeda dari penelitian Robiyanto \& Pangestuti (2020) yang hanya meneliti pada kondisi normal, maka perlu dilakukan penelitian serupa. Mulai tanggal 13 Maret 2020, Otoritas Jasa Keuangan (OJK) memberlakukan regulasi yang baru, yakni ketentuan Auto Reject Bawah (ARB) menjadi 7\% untuk seluruh fraksi harga serta meniadakan saham-saham yang bisa diperdagangkan pada sesi pra-pembukaan (Bursa Efek Indonesia, 2020). Selain itu, ada perbedaan dalam penelitian ini yaitu data penutupan harga saham diambil dari periode Januari 2017 sampai dengan Desember 2020.

Tujuan dari penelitian ini adalah untuk mengkaji risiko sistematis pada dua periode pasar yang berbeda (bullish dan bearish) di Bursa Efek Indonesia (BEI) serta menjelaskan adanya hubungan beta saham pada saat kondisi pasar bullish dan bearish terhadap return saham di BEI. Data yang digunakan dalam penelitian ini adalah data harga saham penutupan 
harian saham-saham terpilih dan penutupan harian IHSG periode 02 Januari 2017 sampai dengan 30 Desember 2020, dengan data yang diperoleh dari Investing. Manfaat dari penelitian ini adalah mampu memberikan bukti empiris pengujian beta saham pada pasar bullish dan pasar bearish di Indonesia yang dapat digunakan oleh investor untuk mengambil keputusan dalam melakukan investasi. Selain itu, dapat menjadi bahan referensi akademisi dalam melakukan penelitian kajian beta saham pada kondisi pasar bullish dan bearish.

\section{Landasan Teori}

\section{Capital Asset Pricing Model (CAPM)}

CAPM merupakan metode yang menghubungkan antara beta (risiko sistematis) dengan expected return sebuah aset pada kondisi pasar yang seimbang (equilibrium). Menurut Hartono (2015), CAPM merupakan sebuah teori untuk menilai risiko dan return aset yang didasarkan koefisien beta (risiko sistematis). Risiko ini terkait dengan makro ekonomi yang sulit dikendalikan, sehingga mempengaruhi kondisi pasar domestik. Faktor-faktor tersebut menyebabkan adanya perubahan dari segi Gross Domestic Product (GDP), inflasi, tingkat suku bunga dan nilai tukar (Respati et al, 2018).

Pengujian model CAPM juga dilakukan oleh Nur Indriantoro (2013) dan Sudarsono et al, (2017) yang menyatakan bahwa dalam mengkaji CAPM digunakan metode two-steps regression, yaitu first pass menggunakan time series regression untuk menguji beta dan second pass menggunakan cross sectional regression untuk menguji berbagai kesalahan dalam melakukan pengujian beta, sehingga menghasilkan slope Security Market Line (SML). Pengujian CAPM dengan single beta, akan menghasilkan off-set antara bull beta dengan bear beta, sehingga hubungan antara beta dengan return saham menjadi tidak signifikan. Sedangkan, pengujian conditional CAPM (dual beta) akan menghasilkan perbedaan, yaitu pada saat market bullish menghasilkan slope positif dan pada market bearish menghasilkan slope negatif.

\section{Bull Beta dan Bear Beta}

Menurut Hartono (2015), beta merupakan suatu pengukur volatilitas suatu return sekuritas atau portofolio terhadap return pasar. Volatilitas dapat didefinisikan sebagai fluktuasi dari return-return suatu sekuritas atau portofolio dalam suatu periode waktu tertentu. Jika fluktuasi return sekuritas atau portofolio secara statistik mengikuti flkutuasi dari return pasar, maka beta dari portofolio tersebut dikatakan bernilai 1 (satu). Beta bernilai 1 (satu) menunjukkan bahwa risiko sistematik suatu portofolio sama dengan risiko pasar. Sedangkan, beta bernilai lebih dari 1 (satu) dikatakan memiliki risiko yang lebih besar dari tingkat risiko pasar. Saham yang memiliki nilai beta kurang dari 1 (satu) dikatakan sebagai saham yang memiliki risiko yang lebih kecil dari tingkat risiko pasar (Lukito, 2014).

Perbedaan dual beta juga di lakukan oleh Arief (2019) yang menyatakan bahwa untuk menguji beta saham terhadap return saham tidak bersifat stasioner sehingga perlu disesuaikan dengan kondisi pasar yang sedang terjadi. Perhitungan beta saham secara terpisah pada saat pasar sedang bullish dan bearish dilakukan untuk mengantisipasi perubahan kondisi pasar yang terjadi. Jika beta saham berubah, maka return yang disyaratkan akan saham juga perlu disesuaikan (Susanti et al, 2020). Dalam kondisi pasar yang berbeda, Tandelilin (2001) mendefinisikan pasar bullish sebagai suatu kecenderungan pergerakan harga saham yang terus menerus menguat atau naik (upward trend). Sedangkan, kondisi pasar bearish adalah kecenderungan pergerakan harga saham terus menerus melemah atau turun (downward trend). 


\section{Penelitian Terdahulu}

Terdapat perbedaan antara peneliti satu dengan yang lainnya, yakni peneliti Hadita (2011); Yunita (2018) menemukan adanya hubungan positif antara conditional beta dengan return saham dengan menggunakan metode Single Index Model. Ariasih \& Mustanda (2018); Ikadarma, Yandi; Bertuah (2019) menemukan adanya hubungan negatif signifikan antara conditional beta dengan return saham menggunakan metode Single Index Model. Respati et al, (2018); Sembiring et al, (2017) menemukan adanya hubungan positif signifikan antara conditional beta dengan return saham menggunakan metode CAPM serta penelitian Sudarsono et al, (2017); Teh \& Lau (2017) menemukan hubungan yang sebaliknya. Penelitian terdahulu sudah menguji beta saham pada saat pasar bullish dan bearish yang akan menjadi bahan referensi dalam penelitian diringkas pada tabel 1 .

Tabel 1. Penelitian Terdahulu

\begin{tabular}{|c|c|c|c|c|}
\hline No & Peneliti & Variabel & Alat analisis & Hasil Penelitian \\
\hline 1 & $\begin{array}{l}\text { Hadita, (2011), } \\
\text { Yunita, (2018), } \\
\text { (Partono Thomas, } \\
\text { Widiyanto, 2019) }\end{array}$ & $\begin{array}{l}\text { Conditional } \\
\text { beta dan } \\
\text { Return saham } \\
\text { index JII }\end{array}$ & $\begin{array}{l}\text { Single Index Model } \\
\text { menggunakan model } \\
\text { Treynor Index }\end{array}$ & $\begin{array}{l}\text { Portofolio optimal yang dibentuk dari } \\
\text { indeks JII menunjukkan hasil yang } \\
\text { berbeda signifikan antara pasar sedang } \\
\text { bullish dan bearish. }\end{array}$ \\
\hline 2 & $\begin{array}{l}\text { Respati et al, } \\
(2018), \text { Sembiring } \\
\text { et al, (2017), } \\
\text { (Susanti et al, } \\
\text { 2020) }\end{array}$ & $\begin{array}{l}\text { Conditional } \\
\text { beta dan return } \\
\text { saham di BEI }\end{array}$ & $\begin{array}{lr}\text { Estimasi } & \text { Bullish dan } \\
\text { Bearish rengan } \\
\text { model perpindahan } \\
\text { Markov, risiko } \\
\text { sistematis dengan } \\
\text { CAPM r dengan } \\
\text { indikator beta } & \text { Sharpe }\end{array}$ & $\begin{array}{l}\text { Tidak menunjukkan perbedaan risiko } \\
\text { sistematis antara kondisi pasar bullish } \\
\text { dan Bearish. Hasilnya, pada kedua } \\
\text { kondisi tersebut terdapat beta negatif } \\
\text { yang dapat memberikan tingat return } \\
\text { positif }\end{array}$ \\
\hline 3 & $\begin{array}{l}\text { Ariasih \& } \\
\text { Mustanda, } \\
\text { (2018); Ikadarma, } \\
\text { Yandi; Bertuah, } \\
\text { (2019), }\end{array}$ & $\begin{array}{l}\text { Conditional } \\
\text { beta terhadap } \\
\text { return saham } \\
\text { di Indeks LQ- } \\
45 \text { perusahaan } \\
\text { manufaktur }\end{array}$ & Single Index Model & $\begin{array}{l}\text { Single Index Model dapat digunakan } \\
\text { untuk menyusun portofolio optimal. } \\
\text { Analisis portofolio dalam penelitian } \\
\text { ini untuk jangka pendek }\end{array}$ \\
\hline 4 & $\begin{array}{l}\text { Sudarsono et al, } \\
\text { (2017) }\end{array}$ & $\begin{array}{l}\text { Conditional } \\
\text { beta dan } \\
\text { Return saham }\end{array}$ & $\begin{array}{l}\text { Capital Asset Pricing } \\
\text { Model (CAPM) }\end{array}$ & $\begin{array}{l}\text { Tidak menunjukkan perbedaan risiko } \\
\text { sistematis. }\end{array}$ \\
\hline 5 & $\begin{array}{l}\text { Teh \& Lau, } \\
(2017)\end{array}$ & $\begin{array}{l}\text { Conditional } \\
\text { beta terhadap } \\
\text { return saham } \\
\text { di Bursa Efek } \\
\text { Malaysia }\end{array}$ & $\begin{array}{l}\text { CAPM, Fama- } \\
\text { French, three-factor } \\
\text { (FF3F) model }\end{array}$ & $\begin{array}{l}\text { Tidak menunjukkan perbedaan yang } \\
\text { signifikan, peneliti tidak } \\
\text { menggunakan metode cross-sectional }\end{array}$ \\
\hline
\end{tabular}

\section{Metode Penelitian}

\section{Jenis dan Sumber Data}

Penelitian ini menggunakan data harga penutupan saham harian, dan return Indeks Harga Saham Gabungan (IHSG) harian sebagai proksi return saham. Data tersebut diperoleh dari investing.com. Periode pengamatan dalam penelitian ini adalah 02 Januari 2017 hingga 30 Desember 2020. Pada periode 2017 sampai dengan 2020, Bursa Efek Indonesia (BEI) mengikuti kebijakan lima fraksi harga saham yaitu; kategori Rp1 untuk kelompok harga dibawah Rp 200, kategori Rp2 untuk kelompok rentang harga Rp 500, kategori Rp5 untuk 
kelompok harga saham dibawah Rp 2.000, kategori Rp 10 untuk kelompok harga dibawah Rp 5.000 dan kategori Rp 25 untuk kelompok harga lebih dari sama dengan Rp 5.000, sehingga penelitian ini mengklasifikasikan harga saham sesuai dengan fraksi harga yang sudah ditetapkan oleh BEI.

\section{Populasi dan Sampel}

Populasi yang digunakan dalam penelitian ini meliputi saham-saham indeks LQ-45 yang terdaftar di Bursa Efek Indonesia (BEI). Metode pengambilan sampel yang digunakan adalah menggunakan metode purposive sampling dengan kriteria, yaitu: (1) tidak pernah melakukan pemecahan saham (stock split), (2) tidak pernah ditangguhkan (suspended), dan (3) diperdagangkan secara aktif selama periode pengamatan. Kriteria ini digunakan karena pemecahan saham (stock split) dapat menimbulkan bias dalam perhitungan return saham. Kemudian, penangguhan perdagangan saham juga dapat menimbulkan bias dalam perhitungan return saham yang menyebabkan return saham bernilai nol karena tidak ada aktivitas perdagangan saham saat ditangguhkan (Tandelilin, 2001). Sebanyak 20 saham bisa memenuhi kriteria tersebut. Nama-nama stok yang termasuk dalam sampel disajikan pada tabel 2.

Tabel 2. Sampel Perusahaan

\begin{tabular}{|c|c|c|c|}
\hline No & Kode Saham & No & Kode Saham \\
\hline 1 & ADRO & 11 & BBTN \\
\hline 2 & AKRA & 12 & CTRA \\
\hline 3 & BBRI & 13 & EXCL \\
\hline 4 & INTP & 14 & INCO \\
\hline 5 & KLBF & 15 & INKP \\
\hline 6 & PGAS & 16 & ITMG \\
\hline 7 & PTBA & 17 & PTPP \\
\hline 8 & SMGR & 18 & PWON \\
\hline 9 & TPIA & 19 & TLKM \\
\hline 10 & ACES & 20 & WIKA \\
\hline
\end{tabular}

\section{Definisi Operasional Variabel}

Penelitian ini menggunakan model dan langkah analisis sebagai berikut:

1. Menghitung return saham individu

Return saham dapat dihitung dengan rumus:

Dimana:

$$
R_{t}=\frac{P_{t}-P_{t-1}}{P_{t-1}}
$$

$\mathrm{R}_{\mathrm{t}}=$ return saham pada hari ke- $\mathrm{t}$

$\mathrm{P}_{\mathrm{t}}=$ harga saham hari ke- $\mathrm{t}$

$\mathrm{P}_{\mathrm{t}-1} \quad=$ harga saham pada hari ke $\mathrm{t}-1$

2. Menghitung return pasar

Tingkat pengembalian (return) pasar didasarkan pada perkembangan indeks pasar. IHSG adalah indeks yang mengukur kinerja seluruh saham yang tercatat di Bursa Efek Indonesia (BEI). Perhitungan tingkat pengembalian pasar dapat dihitung dengan rumus sebagai berikut: 
Dimana:

Yuvica Lara Rovantiane, Robiyanto

$$
R_{m t}=\frac{I H S G_{t}-I H S G_{t-1}}{I H S G_{t-1}}
$$

IHSG $_{\mathrm{t}}=$ Indeks Harga Saham Gabungan pada hari ke-t

$\mathrm{IHSG}_{\mathrm{t}-1}=$ Indeks Harga Saham Gabungan pada hari sebelumnya (t-1)

3. Risiko Sistematis

Risiko sistematis (systematic risk) merupakan risiko yang tidak dapat dihindari. Risiko sistematis sering disebut dengan beta $(\beta)$. Beta adalah alat ukur kerentanan (volatilitas) return suatu pasar. Oleh karena itu beta merupakan pengukur risiko sistematis dari suatu sekuritas atau portofolio terhadap risiko pasar (Wibisono, 2017). Beta dihitung dengan menggunakan rumus:

$$
\beta=\frac{\operatorname{Cov}\left(R_{i} R_{m}\right)}{\sigma_{m}^{2}}
$$

Dimana:

$\beta=$ Beta portofolio

$\operatorname{Cov}\left(R_{i} R_{m}\right)=$ Kovarian return portofolio terhadap return pasar

$\sigma_{m}^{2} \quad=$ Varian return saham

4. Berkenaan dengan beta saham, untuk membedakan kondisi pasar bullish dan bearish, penelitian ini menggunakan metode Bhardwaj \& Brooks (1993) dan Robiyanto \& Pangestuti (2020) yang mengklasifikasikan bulan termasuk kondisi bullish maupun bearish tergantung dari nilai return pasar lebih tinggi atau lebih rendah dari rata-rata (mean) return pasar selama periode pengamatan. Apabila ditemukan return pasar bulan tertentu lebih tinggi dari mean maka termasuk golongan kondisi pasar bullish. Jika ditemukan return pasar bulan tertentu lebih rendah dari tingkat mean, maka digolongkan sebagai kondisi pasar bearish.

\section{Hasil dan Pembahasan}

Dari hasil penelitian 20 saham yang terpilih diantaranya terdapat 12 saham yang lebih tinggi dari mean dan 8 saham yang lebih rendah dari mean. Kemudian, terdapat 459 hari return pasar saham lebih rendah dari mean, dan sebaliknya terdapat 506 hari return pasar lebih tinggi dari mean. Hasil perhitungan beta diringkas dalam tabel 3 dan 5 dibawah ini. Hasil pengujian paired sample t-test untuk keseluruhan periode, bullish periode dan bearish periode dilampirkan pada Tabel 5.

Tabel 3. Perhitungan Beta

\begin{tabular}{|c|c|c|c|}
\hline & All Period & Bearish Period & Bullish Period \\
\hline ACES & 0.92 & 0.99 & 1.11 \\
\hline ADRO & 1.47 & 1.47 & 1.29 \\
\hline AKRA & 1.13 & 1.10 & 1.20 \\
\hline BBRI & 1.59 & 1.51 & 1.74 \\
\hline BBTN & 1.67 & 1.74 & 1.38 \\
\hline CTRA & 1.50 & 1.64 & 1.02 \\
\hline EXCL & 1.52 & 1.40 & 1.79 \\
\hline INCO & 1.45 & 1.38 & 1.56 \\
\hline INKP & 1.75 & 1.80 & 1.72 \\
\hline INTP & 0.08 & 0.19 & 0.11 \\
\hline ITMG & 1.17 & 1.21 & 1.08 \\
\hline
\end{tabular}


INOBIS: Jurnal Inovasi Bisnis dan Manajemen Indonesia

Volume 04, Nomor 03, Juni 2021

Yuvica Lara Rovantiane, Robiyanto

\begin{tabular}{|c|c|c|c|}
\hline KLBF & 1.07 & 0.99 & 1.02 \\
\hline PGAS & 1.67 & 1.75 & 1.71 \\
\hline PTBA & 1.20 & 1.36 & 1.25 \\
\hline SMGR & 1.47 & 1.44 & 1.41 \\
\hline TPIA & 0.54 & 0.79 & 0.31 \\
\hline PTPP & 1.73 & 1.84 & 1.43 \\
\hline PWON & 1.54 & 1.38 & 1.49 \\
\hline TLKM & 1.24 & 1.05 & 1.37 \\
\hline WIKA & 1.68 & 1.88 & 1.55 \\
\hline
\end{tabular}

Tabel 4. Perhitungan Beta berdasarkan Fraksi Harga

\begin{tabular}{|c|c|c|c|}
\hline & All Period & Bearish Period & Bullish Period \\
\hline Golongan 1 & 1.45 & 1.48 & 1.31 \\
\hline Golongan 2 & 1.40 & 1.38 & 1.49 \\
\hline Golongan 3 & 1.00 & 1.08 & 0.93 \\
\hline
\end{tabular}

Tabel 5. Rangkuman Perhitungan Beta

\begin{tabular}{|c|c|c|c|}
\hline & All Period & Bearish Period & Bullish Period \\
\hline Mean & 1.32 & 1.34 & 1.28 \\
\hline Maximum & 1.75 & 1.88 & 1.79 \\
\hline Minimum & 0.08 & 0.19 & 0.11 \\
\hline Standard Deviation & 0.43 & 0.42 & 0.44 \\
\hline $\mathrm{N}$ & 965 & 459 & 506 \\
\hline
\end{tabular}

Fraksi harga (tick size) merupakan satuan perubahan harga saham dalam aktivitas perdagangan saham di pasar reguler (Bursa Efek Indonesia, 2021). Peneliti mengklasifikasikan rentang harga saham sesuai dengan fraksi harga yang sudah ditetapkan oleh BEI. Selanjutnya, menghitung nilai mean berdasarkan beta dari masing-masing periode yakni, beta pada bullish periode, beta pada bearish periode dan beta pada keseluruhan periode. Sehingga, peneliti mendapatkan hasil pada tabel 4. Pertama, untuk golongan 1 dalam kategori fraksi harga saham Rp5 dengan rentang harga Rp500 - < Rp2.000 ditemukan pada saham ACES, ADRO, BBTN, CTRA, KLBF, PTPP, PWON dan PGAS. Pada golongan 1 didapati nilai mean pada beta keseluruhan sebesar 1.45 lebih kecil daripada mean beta bearish yang sebesar 1.48, lalu pada beta bullish didapati mean sebesar 1.31. Kedua, untuk golongan 2 dalam kategori fraksi harga saham Rp10 dengan rentang harga Rp2.000 - < Rp5.000 ditemukan pada saham AKRA, BBRI, EXCL, INCO, PTBA, TLKM dan WIKA. Pada golongan 2 didapati nilai mean keseluruhan sebesar 1.40 lebih besar daripada mean beta bearish yang sebesar 1.38 dan lebih tinggi nilai mean pada beta bullish sebesar 1.49. Ketiga, untuk golongan 3 dalam kategori fraksi harga saham Rp25 dengan rentang harga yang lebih dari Rp 5.000 ditemukan pada saham INKP, INTP, ITMG, SMGR dan TPIA. Pada golongan 3 didapati mean beta keseluruhan sebesar 1.00 lebih kecil daripada nilai mean beta bearish sebesar 1.08 dan nilai mean pada beta bullish sebesar 0.93 .

Tabel 5 menunjukkan bahwa beta rata-rata selama keseluruhan periode adalah 1.32, sedangkan beta tertinggi adalah 1.75 didapat dari saham PT. Indah Kiat Pulp and Paper Tbk (INKP) serta beta terendah dari keseluruhan periode adalah 0.08 yang ditemukan oleh saham 
PT. Indocement Tunggal Prakarsa Tbk (INTP). Temuan ini menunjukkan bahwa saham INKP merupakan saham yang memiliki pergerakan harga paling berfluktuasi (volatile) dari keseluruhan periode. Nilai rata-rata pada periode bearish adalah 1.34, sedangkan beta tertinggi pada periode bearish adalah 1.88 yang ditemukan pada saham PT. Wijaya Karya (WIKA) dan nilai beta terendah pada periode bearish adalah 0.19 yang ditemukan pada saham INTP. Temuan ini menunjukkan bahwa saham WIKA merupakan saham yang paling berfluktuasi pada periode pasar sedang bearish, sebaliknya saham INTP merupakan saham yang paling tidak berfluktuasi pada periode bearish. Beta rata-rata pada periode bullish sebesar 1.28 dengan beta tertinggi sebesar 1.79 terdapat pada saham PT. XL Axiata Tbk (EXCL) serta beta terendah dalam periode bullish sebesar 0.11 terdapat pada saham INTP. Hasil temuan ini menunjukkan bahwa saham WIKA merupakan saham paling berfluktuasi pada periode bullish, sedangkan INTP adalah saham paling tidak berfluktuasi pada periode pasar sedang bullish.

Tabel 6 membuktikan bahwa tidak ada nilai $t$ yang signifikan pada tingkat kepercayaan 95\%. Oleh karena itu dapat disimpulkan bahwa tidak ada perbedaan antara periode keseluruhan dengan periode bullish, dan juga tidak ada perbedaan antara periode keseluruhan dan periode bearish. Demikian juga tidak ada perbedaan yang signifikan antara periode bullish dan periode bearish. Temuan ini sesuai dengan penelitian yang dilakukan oleh Robiyanto \& Pangestuti (2020) yang menemukan bahwa tidak terdapat perbedaan antara bull beta dan bear beta. Ketidaksesuaian ini mungkin saja terjadi, karena studi-studi lain tersebut telah dilakukan di negara yang sudah maju, sedangkan studi ini dilakukan di pasar negara berkembang, dimana pasar negara berkembang cenderung tersegmentasi (Handayani et al, 2018).

Table 6. Hasil dari Paired Samples t-Test

\begin{tabular}{|c|c|c|c|}
\hline & t & df & Sig.(2-tailed) \\
\hline All Period - Bullish Period & -0.968 & 19 & 0.35 \\
\hline All Period - Bearish Period & 1.021 & 19 & 0.32 \\
\hline Bullish Period - Bearish Period & 1.136 & 19 & 0.27 \\
\hline
\end{tabular}

\section{Simpulan}

Hasil penelitian menunjukkan tidak ada perbedaan beta saham dari periode keseluruhan, periode bullish dan periode bearish. Pada kejadian luar biasa di tahun 2020 dengan adanya pandemi COVID-19, hasil studi tersebut menunjukan bahwa beta pada periode bullish cenderung lebih rendah dibandingkan dengan periode keseluruhan dan beta pada periode bearish cenderung lebih tinggi dibandingkan dengan periode keseluruhannya. Artinya, saham-saham pada periode bullish cenderung tidak berfluktuasi, dan sebaliknya saham-saham pada periode bearish cenderung lebih berfluktuasi. Hasil temuan menunjukkan bahwa dalam kondisi bearish dan bullish saham-saham cenderung lebih sensitif terhadap fluktuasi pasar saham. Studi tersebut juga menemukan bahwa saham-saham tertentu, seperti ADRO, BBRI, BBTN, CTRA, EXCL, PTPP, PGAS, PWON dan WIKA memiliki nilai bullish yang lebih besar daripada beta bearish dan beta periode secara keseluruhan.

\section{Implikasi}

Hasil penelitian ini mengimplikasikan bahwa untuk berinvestasi dan merencanakan portofolionya, investor dan manajer investasi dalam jangka panjang tidak perlu memisahkan periode bullish dan periode bearish dalam perhitungan risiko sistematis. Namun demikian, untuk perdagangan saham dengan jangka waktu yang pendek, investor atau trader dapat memperhatikan kondisi pasar yang sedang terjadi agar memperoleh return yang maksimal dan dapat meminimalkan risiko. Investor maupun trader dapat melakukan perdagangan saham 
terutama pada saham beta bullish tinggi atau ketika pasar sedang bullish, dan sebaliknya menghindari saham pada beta bearish tinggi atau pada saat bearish. Untuk menjalankan strategi ini, investor ataupun trader melakukan transaksi pada saham yang diperdagangkan secara aktif.

\section{Keterbatasan dan Saran}

Keterbatasan pada penelitian ini periode pengamatan menggunakan data return pasar dan data return saham selama 965 hari, objek penelitian hanya ditargetkan pada perusahaan yang masuk dalam Indeks LQ-45 dan tidak semua perusahaan dapat bertahan pada Indeks LQ45. Peneliti selanjutnya dapat menggunakan data return pasar dan return saham dengan waktu yang lebih panjang serta menggunakan indeks harga saham selain yang digunakan dalam penelitian ini dan menggunakan saham yang termasuk dalam kategori lain.

\section{Daftar Pustaka}

Ariasih, N. L. P. I., \& Mustanda, I. K. (2018). Pembentukan Portofolio Optimal Menggunakan Model Indeks Tunggal pada Saham Indeks LQ-45. E-Jurnal Akuntansi Universitas Udayana, 1-30. https://doi.org/10.24843/ejmunud.2020.v09.i02.p08

Arief, M. Y. (2019). Portofolio Reksadana Optimal Saham Bluechip pada Kondisi Pasar Saham Bearish dan Bullish. Jurnal Aplikasi Bisnis Dan Manajemen, 5(2), 278-284. https://doi.org/10.17358/jabm.5.2.278

Bhardwaj, R. K., \& Brooks, L. R. D. (1993). Dual Betas From Bull and Bear Markets: Reversal of the Size Effect. Journal of Financial Research, 16(4), 269-283. https://doi.org/10.1111/j.1475-6803.1993.tb00147.x

Bursa Efek Indonesia. (2020). BEI Batasi Auto Reject Bawah Jadi 7 Persen. https://www.idxchannel.com/market-news/

Bursa Efek Indonesia. (2021). Mekanisme Perdagangan Efek. https://idx.co.id/investor/mekanisme-perdagangan/

Febriyanti, G. A. (2020). Dampak Pandemi COVID-19 terhadap Harga Saham dan Aktivitas Volume Perdagangan (Studi Kasus Saham LQ-45 di Bursa Efek Indonesia). Indonesia Accounting Journal, 2(5), 87-91. https://ejournal.unsrat.ac.id/

Hadita, J. (2011). Analisis Perbandingan Kinerja Portofolio Saham - Saham Jakarta Islamic Index pada Pasar Bullish dan Bearish. Tazkia Islamic Finance and Bussines Review, 6, 50-64. https://doi.org/http://dx.doi.org/10.30993/tifbr.v6i1.51

Handayani, H., Muharam, H., Mawardi, W., \& Robiyanto, R. (2018). Determinants of the Stock Price Volatility in the Indonesian Manufacturing Sector. International Research Journal of Business Studies, 11(3), 179-193. https://doi.org/10.21632/irjbs.11.3.179-193

Hartono, J. (2015). Teori portofolio dan Analisis Investasi. BPFE Universitas Gadjah Mada. https://library.bpk.go.id/koleksi/detil/jkpkbpkpp-p-NokRqwa4W2

Ikadarma, Yandi; Bertuah, E. (2019). Optimalization Stock Portfolio Based on Single Index Model over Bullish and Bearish Market: Case Study on LQ-45 Manufacturing Company. Journal of Multidiciplinary Academics, 3(1), 35-41. http://www.kemalapublisher.com/index.php/JoMA/article/view/350

Investing.com. (2021). Jakarta Stock Exchange Composite Index Historical Data. https://www.investing.com/indices/idx-composite-historical-data

Khoiriah, M., Amin, M., \& Kartikasari, A. F. (2020). Pengaruh Sebelum dan Saat Adanya Pandemi COVID-19 Terhadap Saham LQ-45 di Bursa Efek Indonesia Tahun 2020. Jurnal ASET

Riset),

9(2),

117-126. 
http://www.riset.unisma.ac.id/index.php/jra/article/view/8538

Lukito, I. (2014). Penerapan Metode CAPM (Capital Asset Pricing Model) Untuk Menentukan Pilihan Investasi Saham (Studi pada Perusahaan Sektor Consumer Good Industry di Bursa Efek Indonesia Periode 2010-2012). Jurnal Administrasi Bisnis S1 Universitas Brawijaya, 13(2), 84050. https://media.neliti.com/media/publications/87360

Mudjiyono, M. (2018). Investasi dalam Saham \& Obligasi dan Meminimalisasi Risiko Sekuritas pada Pasar Modal Indonesia. Jurnal STIE Semarang, 4(2), 1-18. http://jurnal3.stiesemarang.ac.id/index.php/jurnal/article/view/165

Nur Indriantoro, B. S. (2013). Metodologi Penelitian Bisnis untuk Akuntansi \& Manajemen. BPFE Universitas Gadjah Mada. https://openlibrary.telkomuniversity.ac.id/home/catalog/id/105632

Partono Thomas, Widiyanto, Y. A. and H. V. (2019). The Analysis of Optimal Portfolio Forming with Single Index Model on Indonesian Most Trusted Companies. International Research Journal of Finance and Economics, Issue 163 September, 2017, 50-59. http://www.internationalresearchjournaloffinanceandeconomics.com

Respati, P., Purwanto, B., \& Irwanto, A. K. (2018). Estimasi Bullish dan Bearish dengan Model Perpindahan Markov dan Risiko Sistematis (beta) dengan Model Penilaian Modal Sharpe dalam Investasi Saham di Bursa Efek Indonesia, Tahun 2011 - 2016. Jurnal Manajemen Dan Organisasi, 8(3), 221. https://doi.org/10.29244/jmo.v8i3.22471

Robiyanto, \& Pangestuti, I. R. D. (2020). Bull beta VS Bear Beta in the Indonesia Stock $\begin{array}{llll}\text { Exchange. } \quad A B A C & \text { Journal, }\end{array}$ http://www.assumptionjournal.au.edu/index.php/abacjournal/article/view/4758

Sembiring, F. M., Rahman, S., Effendi, N., \& Sudarsono, R. (2017). Single Beta and Dual Beta Models: A Testing of CAPM on Condition of Market Overreactions. Journal of Finance and Banking Review, 2(3), 1-7. https://econpapers.repec.org/RePEc:gtr:gatrjs:jfbr128

Sudarsono, R., Husnan, S., Tandelilin, E., \& Ekawati, E. (2017). Time Varying Beta (Dual Beta): Conditional Market Timing CAPM. Journal of Management and Business, 11(2). https://doi.org/10.24123/jmb.v11i2.221

Sumiari, K. N., \& Putri, W. T. I. (2020). Reaksi Pasar Terhadap Pengumuman COVID-19 di Indonesia. Jurnal Bisnis Dan Kewirausahaan, 16(2580-5614), 232-236. https://doi.org/10.31940/jbk.v16i3.2081

Susanti, E., Ernest Grace, \& Nelly Ervina. (2020). The Investing Decisions during the COVID19 Pandemic by Using the Capital Asset Pricing Model (CAPM) Method in LQ-45 Index Companies. International Journal of Science, Technology \& Management, 1(4), 409-420. https://doi.org/10.46729/ijstm.v1i4.66

Tandelilin, E. (2001). Beta pada Pasar Bullish dan Bearish: Studi Empiris di Bursa Efek Jakarta (BEJ). Jurnal Ekonomi Dan Bisnis Indonesia, 16(2001), 261-272. https://jurnal.ugm.ac.id/jieb/article/view/39826

Teh, K.-S., \& Lau, W.-Y. (2017). The Dual-Beta Model: Evidence from the Malaysian Stock Market. Indonesian Capital Market Review, 9(1), 39-52. https://doi.org/10.21002/icmr.v9i1.6367

Wibisono, D. A. (2017). Pemilihan Saham yang Optimal Menggunakan Capital Asset Pricing Model (CAPM). Jurnal Manajemen \& Kewirausahaan, 5(1), 32-46. https://doi.org/doi.org/10.26905/jmdk.v5i1.1315

Yunita, I. (2018). Single Index Model in Determining Optimal Portfolio Composition of Jakarta Islamic Index ( JII ). International Seminar and Conference on Learning Organization, ISCLO, 2018, 2004, 238-248. https://openlibrarypublications.telkomuniversity.ac.id/index.php/isclo/article/view/70 $28 / 692$ 